P L A N T B R E E D ING A N D S E E D S C I E N C E

DE GRUYTer DOI: 10.1515/plass-2015-0027

Hatice Çokkizgin $^{1 *}$, Yüksel Bölek ${ }^{2}$

${ }^{1}$ Gaziantep University, Vocational School of Higher Education in Nurdağı, Gaziantep Türkiye;

${ }^{2}$ Kahramanmaraş Sütçü İmam University, Faculty of Agriculture, Department of Agricultural Biotechnology, Kahramanmaraş, Türkiye ; e-mail: hcokkizgin@gantep.edu.tr

\section{PRIMING TREATMENTS FOR IMPROVEMENT OF GERMINATION AND EMERGENCE OF COTTON SEEDS AT LOW TEMPERATURE}

\begin{abstract}
Early sowing in cotton is important for obtaining a high and qualiy yield. Since cotton prefers high temperatures to have a good stand establisment, this work is important to determine better performing genotypes or to promote germination and emergence at low temperatures $\left(<20^{\circ} \mathrm{C}\right)$. This research aimed to increase seed germination rate and seed vigour under cold stress conditions. Two cotton genotypes belonging to G. hirsutum L. species (Aydin-110 and Paymaster-2379) were primed with PEG-6000 (200, 300, $400 \mathrm{~g} / \mathrm{L}), \mathrm{KNO}_{3}(2,3$, $4 \%), \mathrm{KH}_{2} \mathrm{PO}_{4}(0.3,0.4,0.5 \mathrm{M}), \mathrm{NaCl}(2,3,4 \%)$ or Mannitol $(2,4,6 \%)$ to determine the best priming medium and its best amount. After priming, seeds were germinated in germination cabin at cold $\left(18^{\circ} \mathrm{C}\right)$ and warm $\left(30^{\circ}\right.$ C) temperatures and some characteristics (germination rates, radicle length, hypocotyl length and seedling length) were analyzed. Priming with $\mathrm{KNO}_{3}(4 \%$ or $2 \%$ ) was found to result in the highest germination rates in both cotton genotypes. The seeds of the genotypes were also primed with 5 -aminolevulinic acid (ALA) $(1,10$, $25 \mathrm{mg} / \mathrm{L})$, gibberellic acid $\left(\mathrm{GA}_{3}\right)(100,250,500 \mu \mathrm{M})$, methyl jasmonate $(\mathrm{MeJA})(1,3,5 \mu \mathrm{M})$, acetylsalicylic acid (ASA) $(1,10,100 \mu \mathrm{M})$ or kinetin $(1,5,10 \mathrm{mg} / \mathrm{L})$ added to $\mathrm{KNO}_{3}(4 \%)$ medium to choose the most effective plant growth regulator (PGR) application and its dose. PGRs were observed to have reverse effects on germination rate. Finally, emergence test was conducted with $\mathrm{KNO}_{3}(4 \%)$ and $\mathrm{KNO}_{3}(2 \%)$ using metabolic chill test, and some traits (radicle length, radicle weight, hypocotyl length, hypocotyl weight, seedling length, seedling fresh weight and seedling dry weight) were examined. Our results suggested that priming with $\mathrm{KNO}_{3}$ (2\%) might be an effecient way to have vigourous cotton plants under the cold stress.
\end{abstract}

Key words: cotton, emergence, germination, low temperature, PGR, priming

Communicated by Grzegorz Żurek 


\section{INTRODUCTION}

Cotton is the most important source of natural fiber used in textile industry. Increasing the yield and the fiber quality is the main goal of most breeding programs (Mert et al., 2003). Many studies were conducted to produce cottons with high germination and emergence rates in various environmental conditions. Many researchers and producers aim at having seeds with a high quality. Germination and emergence duration of cotton seeds whose quality may change dependently on their germination rates, and climate and soil conditions (Shaheen et al., 2012). To increase the stress tolerance in seeds, treatments, such as hormones, PGRs and various chemicals are commonly used. Many plant species, especially the ones with a tropical or sub-tropical origin, suffer injury when they are exposed to temperatures between the freezing point of tissue $\left(0^{\circ} \mathrm{C}\right)$ and approximately $15^{\circ} \mathrm{C}$. This injury is termed as chilling injury so as to distinguish it from freezing injury (Theocharis et al., 2012). Many economically important crops, such as cotton, soybean, maize, rice and many tropical and sub-tropical fruits are classified as chilling-sensitive (Lyons, 1973; Azymi et al., 2012).

When the amounts of oil, protein, carbonhydrate, ash, fiber and gossypol present in germinating cotton seeds were examined, it was found that most of the reduction in seed dry coat weight, oil, protein and carbohydrate consuption ${ }^{\circ}$ Ccured eight days after germination. Total phospholipid percentage, on the other hand, was observed to increase during germination while phospholipid structures were changing (El-Nockrashy et al., 2006). Since vegetative period in cotton takes a relatively long time, producers might prefer early (sub of optimum temperature for cotton growing) sowing; however, it needs to be considered that cotton radicle formation and growing stop when the soil temperature drops below $14.5^{\circ} \mathrm{C}$ (Jackson, 1986). Because temperature is so critical for cotton sowing, seedlings of the cotton seeds may be delayed, consequently growth rate may be decreased. In order to overcome this obstacle, a variety of methods were developed to promote rapid germination in different environments by considering that seed quality and germination potential are also crucial in cotton production. Generally, polyethylene glycol with varying molecular weight (PEG-6000/8000) and certain osmotic pressure of potassium and sodium composites $\left(\mathrm{K}_{3} \mathrm{PO}_{4}, \mathrm{KH}_{2} \mathrm{PO}_{4}, \mathrm{KNO}_{3}\right.$ or $\left.\mathrm{NaCl}\right)$ are used in priming (GhassemiGolezani et al., 2008; Ghassemi-Golezani et al., 2013; Hameed et al., 2013; Arif et al., 2014). These priming techniques are chosen because they were shown to improve the seed vigor, to increase the germination rate and to trigger the seedling growth (Dastanpoor et al., 2013; Hussian et al., 2014). Thanks to these chemicals used in priming, the first stage of germination takes place in optimum conditions, therefore seeds become tolerant to stress conditions. 
This study aimed to test the effects of different chemicals and PGRs as priming agents on the germination and emergence of cotton seeds using $18^{\circ} \mathrm{C}$ germination test developed for cold stress testing.

\section{MATERIAL AND METHODS}

\section{Plant materials}

Two genotypes, Aydın-110 and Paymaster-2379, having 72.50 and $85.63 \%$ germination rates at $18^{\circ} \mathrm{C}$ respectively, were selected from a preliminary work using the same seed lot. Aydın-110 was developed by Nazilli Cotton Research Center in Turkey and Paymaster-2379 was obtained from an institute located in USA. According to the definiton used by researchers (Smith and Varvil, 1984; Duesterhaus et al., 2000) the former genotype is known as cold sensitive whilst the latter is described as cold tolerant.

\section{Chemicals, PGRs and their applications}

Priming was conducted at two levels: Firstly, the best chemical and its dose for priming medium were determined then the effect of PGRs on priming was tested. The chemicals and their doses (given inside the parentheses) investigated through this study were PEG-6000 (200, 300, $400 \mathrm{~g} / \mathrm{L}), \mathrm{KNO}_{3}(2,3,4 \%)$, $\mathrm{KH}_{2} \mathrm{PO}_{4}(0.3,0.4,0.5 \mathrm{M}), \mathrm{NaCl}(2,3,4 \%)$, Mannitol $(2,4,6 \%)$ and the PGRs examined here were 5-aminolevulinic acid (ALA) $(1,10,25 \mathrm{mg} / \mathrm{L})$, gibberellic acid $\left(\mathrm{GA}_{3}\right)(100,250,500 \mu \mathrm{M})$, methil jasmonat (MeJA) $(1,3,5 \mu \mathrm{M})$, acetylsalicylic acid (ASA) $(1,10,100 \mu \mathrm{M})$ and kinetin $(1,5,10 \mathrm{mg} / \mathrm{L})$. All cotton seeds (160 seeds with 4 replications) were treated with all amounts of the chemicals mentioned above and they were kept at $25^{\circ} \mathrm{C}$ for 2 hours. Subsequently, the seeds were washed and dried in a germination cabin at $25^{\circ} \mathrm{C}$ for 20 hours until moisture content of the seeds decreased to $\sim 7.5 \% \pm 1$. Treated seeds and their controls (both distilled water primed seeds and unprimed seeds) were germinated in a germination cabin with cold germination $\left(18^{\circ} \mathrm{C}\right)$ as it was described below.

Primed and dried seeds were rolled with Whatman Paper. Then, the rolls were placed in a plastic container that was placed in a germination cabin at $18^{\circ}$ $\mathrm{C}$ for 7 days. The rolls were opened and germinated seeds (hypocotyl + radicle $>1.5$ inch) were counted. If germination percentages turned out to be higher than $60 \%$ of what was counted on the $7^{\text {th }}$ day, then the seeds were indicated as cold tolerant (Smith and Varvil, 1984; Kerby et al., 1989; Tolliver et al., 1997; Savoy, 2005). After determining the best priming medium and its most effective dose, application of PGRs on the best priming medium was performed. Seeds belonging to Paymaster-2379 and Aydin-110 genotypes were treated with the best germination chemical dose $\left(\mathrm{KNO}_{3}(4 \%)\right)$ and different PGR doses; 5- 
aminolevulinic acid (ALA) $(1,10,25 \mathrm{mg} / \mathrm{L})$, gibberalik asit $\left(\mathrm{GA}_{3}\right)(100,250$, $500 \mu \mathrm{M})$, metil jasmonat (MeJA) $(1,3,5 \mu \mathrm{M})$, asetil salisilik asit (ASA) $(1,10$, $100 \mu \mathrm{M})$, kinetin $(1,5,10 \mathrm{mg} / \mathrm{L})$. After treatment, seeds were followed through the same procedure mentioned above. The same number of the treated seeds were used in both expriments. After the application of germination test, following charecters were measured:

- $\quad$ Cold germination percentages [\%]: Percentage of hypocotyl and radicle length of seedlings $>1.5$ inch.

- $\quad$ Germination rate [\%]: Total percentage of germinated seeds.

- $\quad$ Radicle length [cm]: Radicle length of seedlings on the days 7.

- $\quad$ Hypocotyl length [cm]: Hypocotyl length of seedlings on the days 7.

- $\quad$ Seedling length $(\mathrm{cm})$ : Total length of seedlings from radicle tip to the top at days 7 .

After selecting optimal dose for priming and investigating the effect of PGRs on germination, the best conditions were used to test the emergence of cotton seeds using metabolic chill test, which was applied as follows: Primed and control cotton seeds (distilled water primed seeds and unprimed seeds) were germinated in a germination cabin at $18^{\circ} \mathrm{C}$ for 21 days. Seeds were placed in sand that was wetted until it reached to the field capacity $(3.8 \mathrm{~cm})(7 \mathrm{~kg}$ of sand $+1 \mathrm{~L}$ of water) in a plastic container. The test was performed with six replicates (102 seeds for each treatment). Seeds were covered with dry sand $(2.5 \mathrm{~cm})(4.50 \mathrm{~kg})$ then the containers were kept in a germination cabin at $18^{\circ} \mathrm{C}$ for 21 days. Emerging seedlings from the sand were counted on the $21^{\text {st }}$ day and differences among the genotypes were determined (Duesterhaus et al., 2000).

After the application of metabolic chill test, following traits were analyzed:

- $\quad$ Cold test [\%]: Percentage of hypocotyl and radicle length of seedlings $>1.5$ inch

- $\quad$ Germination rate [\%]: Percentage of germinated seeds.

- $\quad$ Radicle length [cm]: Radicle length of seedlings on the $21^{\text {st }}$ day.

- $\quad$ Radicle weight [g]: Radicle weight of seedlings on the $21^{\text {st }}$ day.

- Hypocotyl length [cm]: Hypocotyl length of seedlings on the $21^{\text {st }}$. day.

- Hypocotyl weight [g]: Hypocotyl weight of seedlings on the $21^{\text {st }}$ day.

- $\quad$ Seedling length $[\mathrm{cm}]$ : Total seedling length from radicle tip to the top on the $21^{\text {st }}$ day.

- $\quad$ Seedling fresh weight [g]: Total weight of seedling cut from the sand surface on thet $21^{\text {st }}$ day.

- $\quad$ Seedling dry weight [g]: Total weight of seedling cut from the sand surface on the $21^{\mathrm{st}}$ day and dried at $70^{\circ} \mathrm{C}$ for 2 days. 
RESULTS

\section{Priming effects of different chemicals on germination of cotton seeds}

\section{Cold germination (\%)}

Priming with $\mathrm{KNO}_{3}$ showed the best vigour rates. Vigour rates were $84.17 \%$. Paymaster-2379 had $89.33 \%$ vigour rate and this rate was higher than Aydın$110(74.63 \%)$ (Figu. 1). When the results for treated and untreated samples were analyzed, the best vigour rate was observed in the conditions where the priming was made with $\mathrm{KNO}_{3}(4 \%)$. Although priming with $\mathrm{NaCl}(2 \%)$ resulted in a higher germination rate than priming with $\mathrm{KNO}_{3}$. Priming with PEG-6000 and $\mathrm{KNO}_{3}$ seemed to trigger lateral roots production better in Aydın-110 compared to control, and this result was similar to what was observed for Paymaster-2379, except priming with $\mathrm{NaCl}$. Mannitol $(2 \%)(81.88 \%)$ was the best priming medium. However, $\mathrm{KH}_{2} \mathrm{PO}_{4}(0.3 \mathrm{M})(50.63 \%)$ was the worst priming medium.

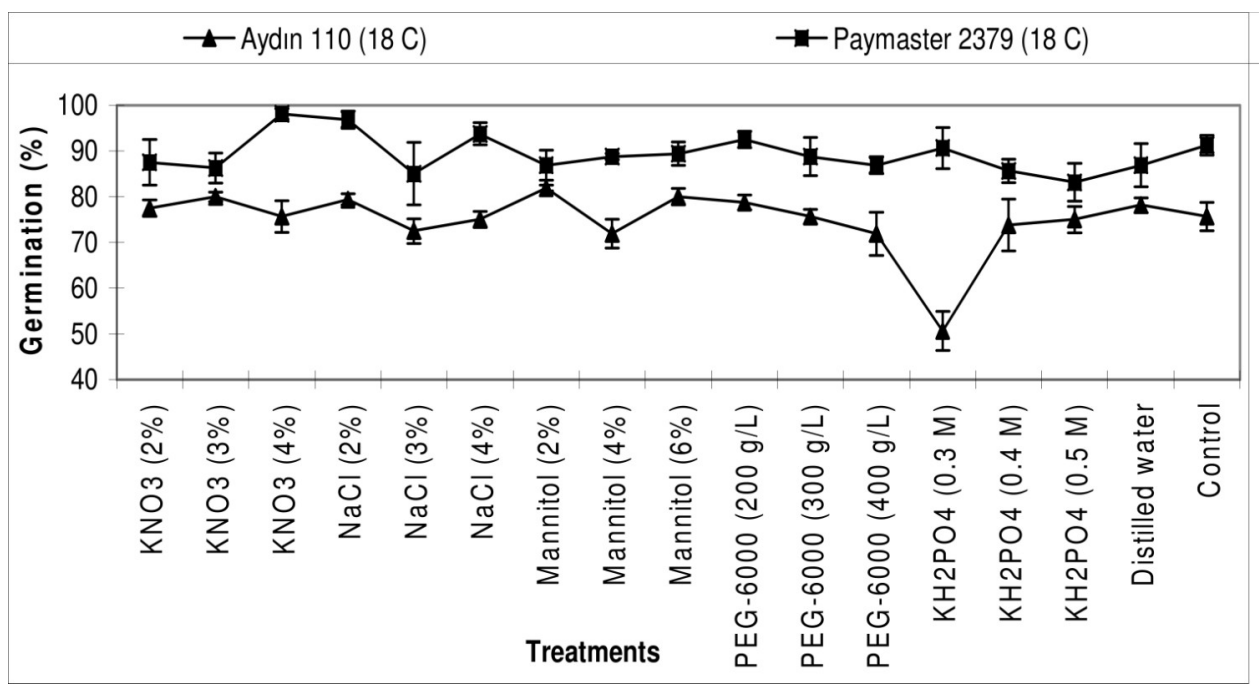

Fig. 1. Cold germination percentages for Aydın 110 and Paymaster 2379 after priming effects of chemicals

The highest vigour rates obtained from $\mathrm{NaCl}(91.88 \%)$ and $\mathrm{KNO}_{3}(90.63 \%)$ and the lowest results belonged to $\mathrm{KH}_{2} \mathrm{PO}_{4}(86.46 \%)$. Compared to the control values, the highest vigour rate was measured when the samples were primed with $\mathrm{KNO}_{3}(4 \%)(98.13 \%)$. The lowest vigour rate $(83.13 \%)$, however, was seen when $\mathrm{KH}_{2} \mathrm{PO}_{4}(0.5 \mathrm{M})$ was used as the priming agent. Comparison of the results of cold germination test is important for cotton cold tolerance (Kerby et al., 1989; Tolliver et al., 1997). It has been known that cold resistant seedlings are taller and heavier than the seedlings that are cold sensitived (Duan et al., 2004; Guler et al., 2007). Besides, seedling radicle and hypocotyl resistance are 
also known to be important for cold tolerance. To estimate the effect of chemicals on seed germination, some other characters, such as seedling length and hypocotyl length were also measured.

\section{Germination rate [\%]}

Priming with $\mathrm{KNO}_{3}(97.40 \%)$ resulted in the highest germination rate while priming with $\mathrm{KH}_{2} \mathrm{PO}_{4}(\% 93.65)$ resulted in the lowest rate. However, the increase in germination rate of Aydın-110 was higher than of Paymaster-2379. Mannitol $(96.77 \%)$ had the highest germination rate. On the contrary, $\mathrm{KNO}_{3}(96.46 \%)$ and $\mathrm{NaCl}(94.90 \%)$ had the lowest germination rates. For Paymaster-2379, the highest germination rates were obtained with $\mathrm{KNO}_{3}$ (4\%) (98.75\%). These results clearly indicated the effect of temperature in germination rate (Table 1).

Table 1

Parameters compared for two cultivars after priming effects of chemicals for cold tolerance

\begin{tabular}{|c|c|c|c|c|c|c|c|c|c|}
\hline \multicolumn{10}{|c|}{$18^{\circ} \mathrm{C}$} \\
\hline \multirow{2}{*}{ Chemical } & \multirow{2}{*}{ Doses } & \multicolumn{2}{|c|}{$\begin{array}{c}\text { Germination rate } \\
{[\%]}\end{array}$} & \multicolumn{2}{|c|}{$\begin{array}{l}\text { Radicle length } \\
{[\mathrm{cm}]}\end{array}$} & \multicolumn{2}{|c|}{$\begin{array}{l}\text { Hyrpocotyl length } \\
{[\mathrm{cm}]}\end{array}$} & \multicolumn{2}{|c|}{$\begin{array}{l}\text { Seedling length } \\
{[\mathrm{cm}]}\end{array}$} \\
\hline & & A-110 & P-2379 & A-110 & P-2379 & A-110 & P-2379 & A-110 & P-2379 \\
\hline $\mathrm{KNO}_{3}$ & $2 \%$ & $97.50^{\mathrm{ab}}$ & $96.25^{\mathrm{a}}$ & $8.84^{\mathrm{a}-\mathrm{c}}$ & $7.51^{\mathrm{ab}}$ & $1.50^{\mathrm{a}-\mathrm{e}}$ & $1.21^{\mathrm{a}}$ & $10.33^{\mathrm{a}-\mathrm{c}}$ & $8.71 \mathrm{ab}$ \\
\hline $\mathrm{KNO}_{3}$ & $3 \%$ & $98.75^{\mathrm{a}}$ & $96.25^{\mathrm{a}}$ & $9.01^{\mathrm{a}-\mathrm{c}}$ & $7.72^{\mathrm{ab}}$ & $1.72^{\mathrm{a}-\mathrm{d}}$ & $1.52^{\mathrm{a}}$ & $10.73^{\mathrm{ab}}$ & $9.24 \mathrm{ab}$ \\
\hline $\mathrm{KNO}_{3}$ & $4 \%$ & $96.88^{\mathrm{ab}}$ & $98.75^{\mathrm{a}}$ & $7.68^{\mathrm{bc}}$ & $8.94^{\mathrm{a}}$ & $1.09^{b-\mathrm{e}}$ & $1.70^{\mathrm{a}}$ & $8.76^{\mathrm{bc}}$ & $10.64 \mathrm{ab}$ \\
\hline $\mathrm{NaCl}$ & $2 \%$ & $98.13^{\mathrm{a}}$ & $98.13^{\mathrm{a}}$ & $9.05^{\mathrm{a}-\mathrm{c}}$ & $8.77^{\mathrm{a}}$ & $1.92^{\mathrm{ab}}$ & $1.95^{\mathrm{a}}$ & $10.97^{\mathrm{ab}}$ & $10.71 \mathrm{a}$ \\
\hline $\mathrm{NaCl}$ & $3 \%$ & $95.63^{\mathrm{ab}}$ & $93.75^{\mathrm{a}}$ & $8.28^{\mathrm{a}-\mathrm{c}}$ & $7.22^{\mathrm{ab}}$ & $1.38^{\mathrm{a}-\mathrm{e}}$ & $1.51^{\mathrm{a}}$ & $9.66^{\mathrm{a}-\mathrm{c}}$ & $8.72 \mathrm{ab}$ \\
\hline $\mathrm{NaCl}$ & $4 \%$ & $96.25^{\mathrm{ab}}$ & $96.25^{\mathrm{a}}$ & $8.15^{\mathrm{a}-\mathrm{c}}$ & $8.85^{\mathrm{a}}$ & $1.05^{\mathrm{edc}}$ & $1.77^{\mathrm{a}}$ & $9.20^{\mathrm{bc}}$ & $10.62 \mathrm{ab}$ \\
\hline Mannitol & $2 \%$ & $99.38^{\mathrm{a}}$ & $90.00^{\mathrm{a}}$ & $9.94^{\mathrm{a}}$ & $7.95^{\mathrm{ab}}$ & $1.87^{\mathrm{a}-\mathrm{c}}$ & $2.28^{\mathrm{a}}$ & $11.81^{\mathrm{a}}$ & $10.23 \mathrm{ab}$ \\
\hline Mannitol & $4 \%$ & $93.13^{\mathrm{ab}}$ & $94.38^{\mathrm{a}}$ & $8.69^{\mathrm{a}-\mathrm{c}}$ & $8.68^{\mathrm{ab}}$ & $1.50^{\mathrm{a}-\mathrm{e}}$ & $1.42^{\mathrm{a}}$ & $10.18^{\mathrm{a}-\mathrm{c}}$ & $10.10 \mathrm{ab}$ \\
\hline Mannitol & $6 \%$ & $100.00^{\mathrm{a}}$ & $92.50^{\mathrm{a}}$ & $9.89^{\mathrm{a}}$ & $8.46^{\mathrm{ab}}$ & $2.10^{\mathrm{a}}$ & $1.36^{\mathrm{a}}$ & $11.99^{\mathrm{a}}$ & $9.83 \mathrm{ab}$ \\
\hline PEG-6000 & $200 \mathrm{~g} / \mathrm{L}$ & $98.75^{\mathrm{a}}$ & $95.63^{\mathrm{a}}$ & $8.59^{\mathrm{a}-\mathrm{c}}$ & $8.59^{\mathrm{ab}}$ & $1.68^{\mathrm{a}-\mathrm{d}}$ & $1.22^{\mathrm{a}}$ & $10.26^{\mathrm{a}-\mathrm{c}}$ & $9.80 \mathrm{ab}$ \\
\hline PEG-6000 & $300 \mathrm{~g} / \mathrm{L}$ & $97.50^{\mathrm{ab}}$ & $91.88^{\mathrm{a}}$ & $7.01^{\mathrm{cd}}$ & $8.66^{\mathrm{ab}}$ & $1.02^{\mathrm{de}}$ & $1.34^{\mathrm{a}}$ & $8.03^{\mathrm{cd}}$ & $10.00 \mathrm{ab}$ \\
\hline PEG-6000 & $400 \mathrm{~g} / \mathrm{L}$ & $95.00^{\mathrm{ab}}$ & $93.13^{\mathrm{a}}$ & $8.29^{\mathrm{a}-\mathrm{c}}$ & $8.39^{\mathrm{ab}}$ & $1.11^{\mathrm{b}-\mathrm{e}}$ & $1.12^{\mathrm{a}}$ & $9.40^{\mathrm{bc}}$ & $9.51 \mathrm{ab}$ \\
\hline $\mathrm{KH}_{2} \mathrm{PO}_{4}$ & $0.3 \mathrm{M}$ & $88.13^{\mathrm{b}}$ & $95.63^{\mathrm{a}}$ & $5.14^{\mathrm{d}}$ & $7.26^{\mathrm{ab}}$ & $0.82^{\mathrm{e}}$ & $1.51^{\mathrm{a}}$ & $5.96^{\mathrm{d}}$ & $8.76 \mathrm{ab}$ \\
\hline $\mathrm{KH}_{2} \mathrm{PO}_{4}$ & $0.4 \mathrm{M}$ & $98.13^{\mathrm{a}}$ & $94.38^{\mathrm{a}}$ & $8.56^{\mathrm{a}-\mathrm{c}}$ & $6.27^{\mathrm{b}}$ & $2.13^{\mathrm{a}}$ & $1.56^{\mathrm{a}}$ & $10.69^{\mathrm{ab}}$ & $7.83 \mathrm{ab}$ \\
\hline $\mathrm{KH}_{2} \mathrm{PO}_{4}$ & $0.5 \mathrm{M}$ & $95.63^{\mathrm{ab}}$ & $90.00^{\mathrm{a}}$ & $8.27^{\mathrm{a}-\mathrm{c}}$ & $6.64^{\mathrm{ab}}$ & $1.44^{\mathrm{a}-\mathrm{e}}$ & $1.10^{\mathrm{a}}$ & $9.71^{\mathrm{a}-\mathrm{c}}$ & $7.74 \mathrm{~b}$ \\
\hline \multicolumn{2}{|c|}{ Distilled water } & $96.25 \mathrm{ab}$ & $90.63^{\mathrm{a}}$ & $9.66^{\mathrm{ab}}$ & $8.45^{\mathrm{ab}}$ & $1.39^{\mathrm{a}-\mathrm{e}}$ & $1.16^{\mathrm{a}}$ & $11.05^{\mathrm{ab}}$ & $9.61^{\mathrm{ab}}$ \\
\hline \multicolumn{2}{|l|}{ Control } & $93.13 \mathrm{ab}$ & $95.00^{\mathrm{a}}$ & $8.92^{\mathrm{a}-\mathrm{c}}$ & $8.30^{\mathrm{ab}}$ & $1.13^{\mathrm{b}-\mathrm{e}}$ & $1.73^{\mathrm{a}}$ & $10.05^{\mathrm{a}-\mathrm{c}}$ & $10.03^{\mathrm{ab}}$ \\
\hline \multicolumn{2}{|l|}{$\mathrm{CV}[\%]$} & 3.93 & 5.37 & 9.40 & 11.81 & 22.53 & 34.01 & 9.43 & 12.11 \\
\hline \multicolumn{2}{|l|}{ Mean } & 96.36 & 94.26 & 8.47 & 8.04 & 1.46 & 1.50 & 9.93 & 9.53 \\
\hline
\end{tabular}

A - Aydın-110, P - Paymaster-2379 


\section{Radicle length [cm]}

Radicle length of Aydın-110 genotype was changed from 5.14 to $9.94 \mathrm{~cm}$ and the mean radicle length was calculated as $8.47 \mathrm{~cm}$. The difference in the mean radicle lengths measured at different temperatures was $1.20 \mathrm{~cm}$, and this can be resulted to the fact enzymatic activity can be slowed by lower temperatures (Table 1). $\mathrm{KNO}_{3}$, PEG-6000, Mannitol were found to increase the radicle length, which suggested that they could be used against the cold and water stress. Mannitol (2\%) treatment resulted in the longest radicle $(9.94 \mathrm{~cm})$ for Aydin-110. Radicle length of Paymaster-2379 was ranged from 6.27 to $8.94 \mathrm{~cm}$. The differences of the lengths between the tests were $1.40 \mathrm{~cm} . \mathrm{KNO}_{3}(4 \%)$ $(8.94 \mathrm{~cm})$ resulted in the highest increase in radicle length.

\section{Hypocotyl length [cm]}

Hypocotyl length of Aydin-110 changed between 0.82 and $2.13 \mathrm{~cm}$ and the mean value was determined as $1.46 \mathrm{~cm}$. High chemical doses caused low hypocotyl length. Mannitol (2\%) (2.28) had the longest hypocotyl length of Paymaster-2379 genotype. $\mathrm{KH}_{2} \mathrm{PO}_{4}(0.5 \mathrm{M})(1.10 \mathrm{~cm})$ resulted in the lowest hypocotyl length (Table 1.).

\section{Seedling length [cm]}

Mannitol $(10.69 \mathrm{~cm})$ provided fast growing seedlings for early harvesting and cold tolerant plants. Mannitol $(\% 2)(11.81 \mathrm{~cm})$ resulted in the longest seedlings while $\mathrm{KH}_{2} \mathrm{PO}_{4}(0.3 \mathrm{M})(5.94)$ caused the production of the shortest seedlings. PEG-6000 $(200 \mathrm{~g} / \mathrm{L})(12.02 \mathrm{~cm})$ had an increasing effect on seedling length. $\mathrm{KNO}_{3}(4 \%)(10.64 \mathrm{~cm})$ generated the longest seedlings. Germination results showed that $\mathrm{KNO}_{3}$ gave the highest result and $\mathrm{KNO}_{3}(4 \%)$ had the highest results thus $\mathrm{KNO}_{3}(4 \%)$ was chosen as the best priming medium.

\section{Priming effects of different PGRs on germination of cotton seeds}

\section{Cold germination [\%]}

The highest vigour rates belonged to the priming with $\mathrm{GA}_{3}$ while MeJA (3 $\mu \mathrm{M})(93.75 \%)$ was determined as the best treatment (Fig.2). ALA (84.69\%) resulted in the lowest vigour rate. ASA $(10 \mu \mathrm{M})$ had the best dose. $\mathrm{GA}_{3}$ showed the highest result for Paymaster-2379. Since the highest vigour rate was obtained with MeJA ( $3 \mu \mathrm{M})$ (Fig. 2), MeJA was chosen as the best PGR for Aydin -110 and Paymaster-2379. 


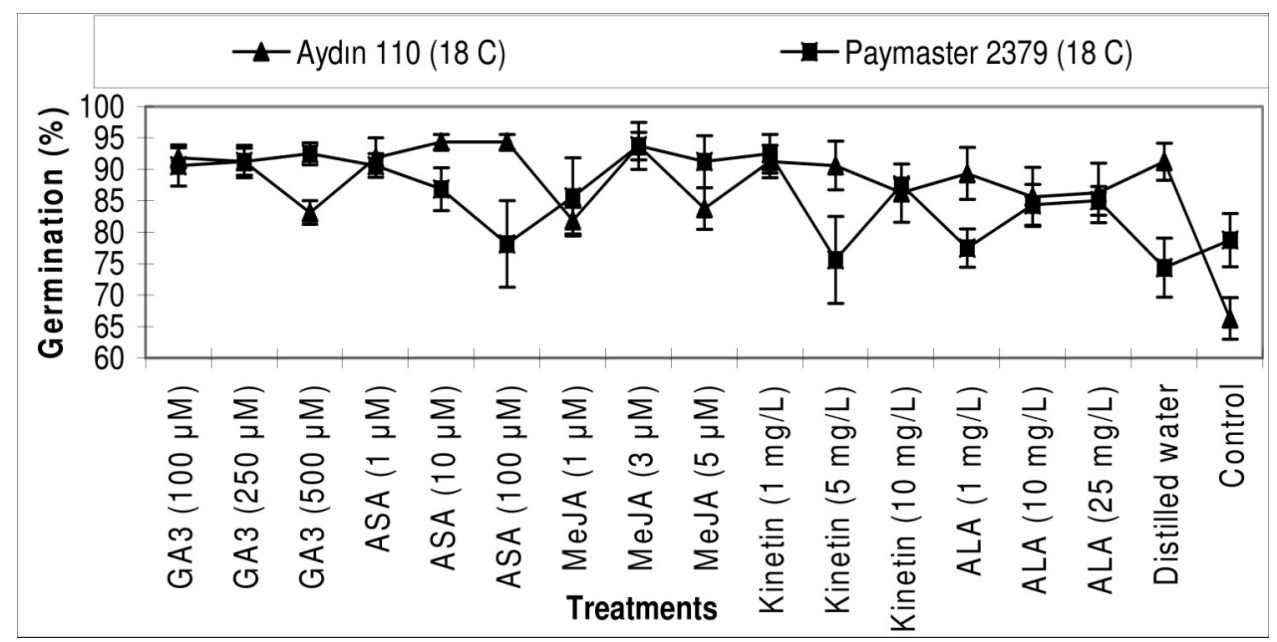

Fig. 2. Cold germination percentages for Aydın 110 and Paymaster 2379 after priming effects of PGRs

\section{Germination rate [\%]}

The highest germination rate was obtained in $\mathrm{GA}_{3}(97.50 \%)$. While $\mathrm{GA}_{3}(250$ $\mu \mathrm{M})$ was determined as the best PGR in terms of its germination rate for Aydin110 , and $\mathrm{GA}_{3}(100 \mu \mathrm{M})$ was picked as the best PGR for Paymaster-2379 were determined the best PGR for germination rate.

\section{Radicle length [cm]}

ASA $(6.35 \mathrm{~cm})$ promoted radicle elongation. While ASA $(10 \mu \mathrm{M})$ generated the best results in Aydin-110, $\mathrm{GA}_{3}(500 \mu \mathrm{M})$ was determined as the best PGR for Paymaster-2379. The longest radicle for Aydın-110 was obtained in distilled water primed seeds. The longest radicle for Paymaster-2379 was produced by MeJA $(1 \mu \mathrm{M})$. Results showed that seeds primed with ASA $(7.69 \mathrm{~cm})$ were different from control (unprimed seeds) (4.15) $3.54 \mathrm{~cm}$ (Table 2).

\section{Hypocotyl length [cm]}

$\mathrm{GA}_{3}$ provided the longest hypocotyl length. $\mathrm{GA}_{3}(250 \mu \mathrm{M})$ was observed as the most effective PGR treatment for both Aydın-110 and Paymaster-2379. (Table 2).

\section{Seedling length [cm]}

$\mathrm{GA}_{3}(7.65 \mathrm{~cm})$ promoted seedling elongation. The longest seedlings were obtained by $\mathrm{GA}_{3}(250 \mu \mathrm{M})$ in Aydın-110 and by $\mathrm{GA}_{3}(500 \mu \mathrm{M})$ in Paymaster2379 (Table 2). The highest results were obtained in MeJA. Germination results showed that PGRs in the best priming medium increased germination parame- 
ters. But this increase was lower than using priming medium alone (Tiryaki and Buyukcingil, 2005). The results were lower when the chemicals $\left(\mathrm{KNO}_{3}(4 \%)\right)$ was mixed with PGRs compared to when the chemical was used alone. According to the emergence test results, the best priming medium was $\mathrm{KNO}_{3}(4 \%)$ and followed by $\mathrm{KNO}_{3}(2 \%)$.

Table 2

Parameters compared for two cultivars after priming effects of PGRs for cold tolerance

\begin{tabular}{|c|c|c|c|c|c|c|c|c|c|}
\hline \multicolumn{10}{|c|}{$18^{\circ} \mathrm{C}$} \\
\hline \multirow{2}{*}{ Chemical } & \multirow{2}{*}{ Doses } & \multicolumn{2}{|c|}{$\begin{array}{c}\text { Germination rate } \\
{[\%]}\end{array}$} & \multicolumn{2}{|c|}{$\begin{array}{l}\text { Radicle length } \\
{[\mathrm{cm}]}\end{array}$} & \multicolumn{2}{|c|}{$\begin{array}{l}\text { Hyrpocotyl length } \\
{[\mathrm{cm}]}\end{array}$} & \multicolumn{2}{|c|}{$\begin{array}{l}\text { Seedling length } \\
{[\mathrm{cm}]}\end{array}$} \\
\hline & & A-110 & P-2379 & A-110 & P-2379 & A-110 & P-2379 & A-110 & P-2379 \\
\hline $\mathrm{GA}_{3}$ & $100 \mu \mathrm{M}$ & $97.50^{\mathrm{a}}$ & $98.75^{\mathrm{a}}$ & $7.03^{\mathrm{a}-\mathrm{c}}$ & $5.78^{\mathrm{a}-\mathrm{c}}$ & $1.57^{\mathrm{ab}}$ & $1.38^{\mathrm{ab}}$ & $8.60^{a-c}$ & $7.16^{\mathrm{ab}}$ \\
\hline $\mathrm{GA}_{3}$ & $250 \mu \mathrm{M}$ & $98.75^{\mathrm{a}}$ & 98.13 & $7.19^{\mathrm{ab}}$ & $5.54^{\mathrm{a}-\mathrm{c}}$ & $1.99^{\mathrm{a}}$ & $1.77^{\mathrm{a}}$ & $9.17^{\mathrm{a}}$ & $7.30^{\mathrm{ab}}$ \\
\hline $\mathrm{GA}_{3}$ & $500 \mu \mathrm{M}$ & $96.25^{\mathrm{a}}$ & $95.63^{\mathrm{ab}}$ & $4.63^{\mathrm{fg}}$ & $6.45^{\mathrm{a}}$ & $1.20^{\mathrm{b}-\mathrm{d}}$ & $1.37^{\mathrm{ab}}$ & $5.83^{\mathrm{fg}}$ & $7.82^{\mathrm{a}}$ \\
\hline ASA & $1 \mu \mathrm{M}$ & $96.88^{\mathrm{a}}$ & $98.13^{\mathrm{ab}}$ & $7.24^{\mathrm{ab}}$ & $6.30^{\mathrm{ab}}$ & $0.94^{\mathrm{cd}}$ & $0.94^{\mathrm{b}-\mathrm{d}}$ & $8.18^{\mathrm{a}-\mathrm{e}}$ & $7.24^{\mathrm{ab}}$ \\
\hline ASA & $10 \mu \mathrm{M}$ & $96.25^{\mathrm{a}}$ & $96.88^{\mathrm{ab}}$ & $7.69^{\mathrm{a}}$ & $5.18^{\mathrm{a}-\mathrm{c}}$ & $1.18^{\mathrm{b}-\mathrm{d}}$ & $1.20^{\mathrm{bc}}$ & $8.87^{\mathrm{ab}}$ & $6.37^{\mathrm{a}-\mathrm{d}}$ \\
\hline ASA & $100 \mu \mathrm{M}$ & $98.13^{\mathrm{a}}$ & $91.88^{\mathrm{ab}}$ & $7.16^{\mathrm{ab}}$ & $4.51^{\mathrm{bc}}$ & $1.15^{\mathrm{b}-\mathrm{d}}$ & $1.09^{\mathrm{b}-\mathrm{d}}$ & $8.31^{\mathrm{a}-\mathrm{d}}$ & $5.60^{\mathrm{b}-\mathrm{d}}$ \\
\hline MeJA & $1 \mu \mathrm{M}$ & $91.25^{\mathrm{a}}$ & $94.38^{\mathrm{ab}}$ & $5.10^{\mathrm{e}-\mathrm{g}}$ & $5.33^{\mathrm{a}-\mathrm{c}}$ & $1.12^{\mathrm{b}-\mathrm{d}}$ & $1.06^{\mathrm{b}-\mathrm{d}}$ & $6.22^{\mathrm{e}-\mathrm{g}}$ & $6.38^{\mathrm{a}-\mathrm{d}}$ \\
\hline MeJA & $3 \mu \mathrm{M}$ & $97.50^{\mathrm{a}}$ & $96.88^{\mathrm{ab}}$ & $6.68^{\mathrm{a}-\mathrm{e}}$ & $6.30^{\mathrm{ab}}$ & $1.44^{\mathrm{a}-\mathrm{c}}$ & $1.18^{\mathrm{bc}}$ & $8.11^{\mathrm{a}-\mathrm{e}}$ & $7.48^{\mathrm{ab}}$ \\
\hline MeJA & $5 \mu \mathrm{M}$ & $93.13^{\mathrm{a}}$ & $94.38^{\mathrm{ab}}$ & $5.56^{\mathrm{b}-\mathrm{g}}$ & $6.28^{\mathrm{ab}}$ & $1.48^{\mathrm{a}-\mathrm{c}}$ & $1.01^{\mathrm{b}-\mathrm{d}}$ & $7.04^{\mathrm{b}-\mathrm{f}}$ & $7.28^{\mathrm{ab}}$ \\
\hline Kinetin & $1 \mathrm{mg} / \mathrm{L}$ & $96.88^{\mathrm{a}}$ & $96.25^{\mathrm{ab}}$ & $6.90^{\mathrm{a}-\mathrm{d}}$ & $5.83^{\mathrm{a}-\mathrm{c}}$ & $1.15^{\mathrm{a}-\mathrm{c}}$ & $1.13^{\mathrm{bc}}$ & $8.06^{\mathrm{a}-\mathrm{e}}$ & $6.96^{\mathrm{a}-\mathrm{c}}$ \\
\hline Kinetin & $5 \mathrm{mg} / \mathrm{L}$ & $98.13^{\mathrm{a}}$ & $93.13^{\mathrm{ab}}$ & $6.46^{\mathrm{a}-\mathrm{e}}$ & 4.21 & $0.94^{\mathrm{a}-\mathrm{c}}$ & $0.87^{\mathrm{cd}}$ & $7.40^{\mathrm{a}-\mathrm{f}}$ & $5.08^{\mathrm{cd}}$ \\
\hline Kinetin & $10 \mathrm{mg} / \mathrm{L}$ & $96.25^{\mathrm{a}}$ & $94.38^{\mathrm{ab}}$ & $5.69^{\mathrm{b}-\mathrm{g}}$ & $4.78^{\mathrm{a}-\mathrm{c}}$ & $0.94^{\mathrm{cd}}$ & $0.86^{\mathrm{cd}}$ & $6.62^{c-g}$ & $5.63^{\mathrm{b}-\mathrm{c}}$ \\
\hline ALA & $1 \mathrm{mg} / \mathrm{L}$ & $92.50^{\mathrm{a}}$ & $93.75^{\mathrm{ab}}$ & $6.13^{\mathrm{a}-\mathrm{f}}$ & $4.55^{\mathrm{bc}}$ & $1.07^{\mathrm{b}-\mathrm{d}}$ & $0.99^{\mathrm{b}-\mathrm{d}}$ & $7.20^{\mathrm{a}-\mathrm{f}}$ & $5.54^{\mathrm{b}-\mathrm{c}}$ \\
\hline ALA & $10 \mathrm{mg} / \mathrm{L}$ & $93.75^{\mathrm{a}}$ & $93.13^{\mathrm{ab}}$ & $5.19^{\mathrm{d}-\mathrm{g}}$ & $5.36^{\mathrm{a}-\mathrm{c}}$ & $0.67^{\mathrm{d}}$ & $1.16^{\mathrm{bc}}$ & $5.86^{\mathrm{gf}}$ & $6.52^{\mathrm{a}-\mathrm{d}}$ \\
\hline ALA & $25 \mathrm{mg} / \mathrm{L}$ & $91.25^{\mathrm{a}}$ & $93.13^{\mathrm{ab}}$ & $5.37^{\mathrm{c}-\mathrm{g}}$ & $4.95^{\mathrm{a}-\mathrm{c}}$ & $1.12^{\mathrm{b}-\mathrm{d}}$ & $1.05^{\mathrm{b}-\mathrm{d}}$ & $6.48^{\mathrm{d}-\mathrm{g}}$ & $6.00^{\mathrm{a}-\mathrm{d}}$ \\
\hline \multicolumn{2}{|c|}{ Distilled water } & & $95.00^{\mathrm{a}}$ & $95.63^{\mathrm{ab}}$ & $6.24^{\mathrm{a}-\mathrm{f}}$ & $4.18^{\mathrm{c}}$ & $0.74^{\mathrm{d}}$ & $0.65^{\mathrm{d}}$ & $6.97^{-\mathrm{g}}$ \\
\hline \multicolumn{2}{|l|}{ Control } & & $93.75^{\mathrm{a}}$ & $88.13^{\mathrm{b}}$ & $4.15^{\mathrm{g}}$ & $4.74^{\mathrm{a}-\mathrm{c}}$ & $0.79^{\mathrm{d}}$ & $0.84^{\mathrm{cd}}$ & $4.94^{\mathrm{g}}$ \\
\hline \multicolumn{2}{|l|}{$\mathrm{CV}[\%]$} & & 3.36 & 4.20 & 11.22 & 13.54 & 21.38 & 15.96 & 10.9 \\
\hline \multicolumn{2}{|l|}{ Mean } & & 95.48 & 94.85 & 6.14 & 5.31 & 1.15 & 1.09 & 7.29 \\
\hline
\end{tabular}

A - Aydın-110, P - Paymaster-2379 


\section{Effects of best priming agent and PGR on emergence of cotton seeds}

\section{Cold germination [\%]}

While $\mathrm{KNO}_{3}(2 \%)$ showed $15.20 \%$ increase in vigour compared to the control, vigour rate in the cells treated with $\mathrm{KNO}_{3}(4 \%)$ was found to be $9.80 \%$ higher than the control (Fig. 3). When $\mathrm{KNO}_{3}(2 \%)$ was applied, $22.55 \%$ increase in germination rate was observed in Aydin-110. This rate was $7.85 \%$ in Paymaster-2379 compared to the control.

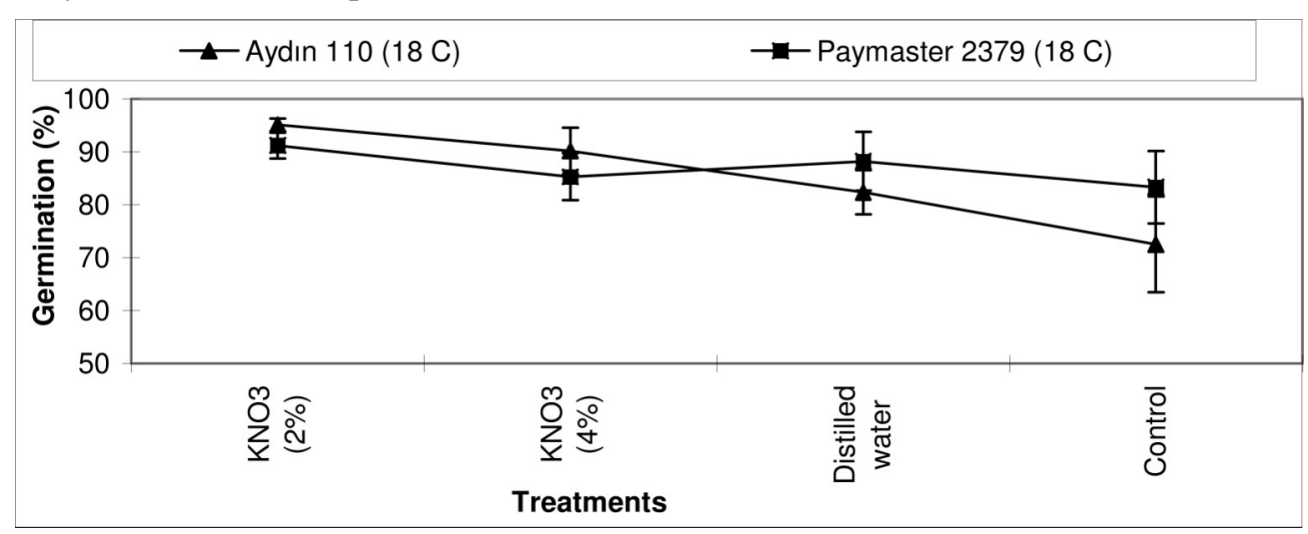

Fig. 3. Cold germination percentages for Aydın 110 and Paymaster 2379 after application of best priming agent and PGR

\section{Germination rate [\%]}

The highest germination rate was obtained with $\mathrm{KNO}_{3}(2 \%)$ (Table 3). $\mathrm{KNO}_{3}$ (2\%) showed $22.55 \%$ and $7.85 \%$ increase in germination rate in comparison with the control of Aydın-110 and Paymaster-2379, respectively.

\section{Hypocotyl length [cm]}

The longest hypocotyl lengths were measured in the seeds treated with $\mathrm{KNO}_{3}$ (4\%) (Table 3). $\mathrm{KNO}_{3}(2 \%)$ showed $1.66 \mathrm{~cm}$ and $0.69 \mathrm{~cm}$ increase in hypocotyl length compared to the control in Aydın-110 and Paymaster-2379, respectively.

\section{Radicle length [cm]}

The highest result was obtained with $\mathrm{KNO}_{3}(2 \%)$. Radicle length was increased $1.49 \mathrm{~cm}$ and $0.13 \mathrm{~cm}$ compared to the control (unprimed seeds) in Aydin-1 10 and Paymaster-2379, respectively (Table 3). However, radicle length of the seedlings generated from $\mathrm{KNO}_{3}(4 \%)$ treated cells was longer than the ones treated with $\mathrm{KNO}_{3}(2 \%)$. The difference in the radicle lengths of the seedlings of $\mathrm{KNO}_{3}(4 \%)$ and $\mathrm{KNO}_{3}(2 \%)$ treated seeds was $0.089 \mathrm{~cm}$. 
Priming treatments for improvement of germination and emergence of cotton ... 131

Table 3

Parameters compared for two cultivars after priming effects of PGRs for cold tolerance

\begin{tabular}{lccccccccc}
\hline Parameter à & CG & GR & HL & RL & SL & RW & HW & SFW & SDW \\
\hline Chemical â & & & \multicolumn{7}{c}{ Aydın-110 } \\
\hline $\mathrm{KNO}_{3}(2 \%)$ & $95.10^{\mathrm{a}}$ & $95.10^{\mathrm{a}}$ & $6.36^{\mathrm{a}}$ & $5.08^{\mathrm{a}}$ & $11.44^{\mathrm{a}}$ & $0.090^{\mathrm{a}}$ & $0.18^{\mathrm{a}}$ & $0.38^{\mathrm{a}}$ & $0.035^{\mathrm{a}}$ \\
$\mathrm{KNO}_{3}(4 \%)$ & $90.20^{\mathrm{ab}}$ & $90.20^{\mathrm{b}}$ & $6.00^{\mathrm{a}}$ & $4.83^{\mathrm{a}}$ & $10.83^{\mathrm{a}}$ & $0.091^{\mathrm{a}}$ & $0.18^{\mathrm{a}}$ & $0.34^{\mathrm{ab}}$ & $0.034^{\mathrm{a}}$ \\
D.water & $82.35^{\mathrm{ab}}$ & $82.35^{\mathrm{ab}}$ & $5.99^{\mathrm{a}}$ & $4.56^{\mathrm{a}}$ & $8.29^{\mathrm{b}}$ & $0.086^{\mathrm{a}}$ & $0.18^{\mathrm{a}}$ & $0.33^{\mathrm{ab}}$ & $0.034^{\mathrm{ab}}$ \\
Control & $72.55^{\mathrm{b}}$ & $72.55^{\mathrm{b}}$ & $4.70^{\mathrm{a}}$ & $3.59^{\mathrm{a}}$ & $10.55^{\mathrm{a}}$ & $0.077^{\mathrm{a}}$ & $0.14^{\mathrm{a}}$ & $0.27^{\mathrm{b}}$ & $0.028^{\mathrm{b}}$ \\
$\mathrm{CV}(\%)$ & 12.89 & 12.89 & 21.86 & 20.72 & 10.89 & 18.87 & 22.72 & 16.64 & 11.58 \\
$\mathrm{Mean}$ & 85.05 & 85.05 & 5.76 & 4.51 & 10.28 & 0.09 & 0.17 & 0.33 & 0.03 \\
\hline $\mathrm{Chemical} \mathrm{â}$ & & & & & Paymaster-2379 & & & \\
\hline $\mathrm{KNO}_{3}(2 \%)$ & $91.18^{\mathrm{a}}$ & $91.18^{\mathrm{a}}$ & $5.39^{\mathrm{a}}$ & $4.61^{\mathrm{a}}$ & $10.00^{\mathrm{a}}$ & $0.087^{\mathrm{a}}$ & $0.16^{\mathrm{ab}}$ & $0.31^{\mathrm{a}}$ & $0.031^{\mathrm{a}}$ \\
$\mathrm{KNO}_{3}(4 \%)$ & $85.30^{\mathrm{a}}$ & $85.30^{\mathrm{a}}$ & $5.17^{\mathrm{a}}$ & $4.70^{\mathrm{a}}$ & $9.87^{\mathrm{a}}$ & $0.069^{\mathrm{a}}$ & $0.15^{\mathrm{ab}}$ & $0.27^{\mathrm{a}}$ & $0.029^{\mathrm{a}}$ \\
$\mathrm{D} . w a t e r$ & $88.24^{\mathrm{a}}$ & $88.24^{\mathrm{a}}$ & $6.15^{\mathrm{a}}$ & $3.77^{\mathrm{a}}$ & $9.93^{\mathrm{a}}$ & $0.079^{\mathrm{a}}$ & $0.18^{\mathrm{a}}$ & $0.32^{\mathrm{a}}$ & $0.030^{\mathrm{a}}$ \\
$\mathrm{Control}$ & $83.33^{\mathrm{a}}$ & $83.33^{\mathrm{a}}$ & $4.70^{\mathrm{a}}$ & $4.49^{\mathrm{a}}$ & $9.19^{\mathrm{a}}$ & $0.076^{\mathrm{a}}$ & $0.13^{\mathrm{b}}$ & $0.27^{\mathrm{a}}$ & $0.031^{\mathrm{a}}$ \\
$\mathrm{CV}(\%)$ & 11.69 & 11.69 & 21.43 & 25.15 & 13.2 & 15.49 & 15.82 & 17.93 & 16.29 \\
$\mathrm{Mean}$ & 87.01 & 87.01 & 5.35 & 4.39 & 9.75 & 0.08 & 0.15 & 0.29 & 0.03 \\
\hline
\end{tabular}

CG: Cold germination, GR: Germination rate, HL: Hypocotyl length, RL: Radicle length, SL: Seedling length, RW: Radicle weight, HW: Hypocotyl weight, SFW: Seedling fresh weight, SDW: Seedling dry weight

\section{Seedling length [cm]}

$\mathrm{KNO}_{3}(4 \%)$ supported the seedling growth $(10.83 \mathrm{~cm})$. The longest seedlings were obtained with $\mathrm{KNO}_{3}(2 \%)$ in all genotypes. $\mathrm{KNO}_{3}(2 \%)$ showed $0.89 \mathrm{~cm}$ and $0.82 \mathrm{~cm}$ increase in seedling length compared to the controls of Aydin-110 and Paymaster-2379, respectively (Table 3).

\section{Radicle weight [g]}

Increase in radicle weight was $0.013 \mathrm{~g}$ and $0.011 \mathrm{~g}$ in the seedlings treated with $\mathrm{KNO}_{3}(2 \%)$ in Aydın-110 and Paymaster-2379, respectively. $\mathrm{KNO}_{3}(2 \%)$ was more effective for radicle weight increase than $\mathrm{KNO}_{3}(4 \%)$ in Paymaster2379 (Table 3). 


\section{Hypocotyl weight [g]}

$\mathrm{KNO}_{3}(2 \%)$ resulted in $0.04 \mathrm{~g}$ and $0.03 \mathrm{~g}$ increase in hypocotyl weight compared to the control in Aydın-110 and Paymaster-2379, respectively. $\mathrm{KNO}_{3}$ $(2 \%)$ and $\mathrm{KNO}_{3}(4 \%)$ showed similar results with only an unremarkable amount of difference for Aydın-110 and Paymaster-2379 (Table 3).

\section{Seedling fresh weight [g]}

Seedling fresh weight $0.11 \mathrm{~g}$ and $0.04 \mathrm{~g}$ increased in $\mathrm{KNO}_{3}(2 \%)$ treated seeds in Aydin-110 and Paymaster-2379, respectively. This result showed that $\mathrm{KNO}_{3}(2 \%)$ was effective on cotton seedlings for cold tolerance. Cotton seed priming with $\mathrm{KNO}_{3}(2 \%)$ can result vigorous seedlings in cold environmental conditions (Table 3 ).

\section{Seedling dry weight [g]}

$\mathrm{KNO}_{3}(2 \%)$ treatment resulted in higher seedling dry weight than $\mathrm{KNO}_{3}(4 \%)$ treatment (Table 3). Emergence test showed that $\mathrm{KNO}_{3}(2 \%)$ was a more effective priming medium, which increased the values in all parameters except the hypocotyl weight of Aydin-110, compared to $\mathrm{KNO}_{3}(4 \%)$ for cotton cold tolerance. When considered together, the results of this study indicates that $\mathrm{KNO}_{3}$ $(2 \%)$ is an effective priming chemical for cold stress conditions.

\section{DISCUSSION}

Cold stress tolerance in seed and different seedling parts increased with different chemicals and doses in priming. The amount of increase seemed to be dependent on germination parameters (germination rate, seedling lenght, hypocotyl length etc.), chemicals and doses. According to our results analyzed with control in comparison, the best vigour rate was measured when the priming was made with $\mathrm{KNO}_{3}(4 \%)$. Although priming with $\mathrm{NaCl}(2 \%)$ resulted in higher values than the ones measured in $\mathrm{KNO}_{3}$ (Figure 1).

Priming with Mannitol (96.77\%) resulted in the highest germination rate and priming with $\mathrm{KNO}_{3}(96.46 \%)$ and $\mathrm{NaCl}(94.90 \%)$ caused the germination of the seeds with the lowest germination rate. The highest germination rate of Aydin110 was determined in Mannitol (6\%) (100.00\%) and the lowest germination rate of the same specimen was measured in $\mathrm{KH}_{2} \mathrm{PO}_{4}(0.3 \mathrm{M})(88.13 \%)$. Saeidi et al. (2008) said that seed priming with $\mathrm{KH}_{2} \mathrm{PO}_{4}$ effective on canola roots. The highest germination rates were obtained with $\mathrm{KNO}_{3}(4 \%)(98.75 \%) . \mathrm{KH}_{2} \mathrm{PO}_{4}$ $(0.5 \mathrm{M})$ produced the low results.

Mannitol is a good priming medium (Kaur et al., 2002) and it showed the highest results in all parameters except hypocotyl length in Aydın-110. The highest results in all parameters of Paymaster-2379, except seedling and hypo- 
cotyl length were obtained, were obtained by $\mathrm{KNO}_{3}$. Germination results showed that $\mathrm{KNO}_{3}(4 \%)$ yielded the highest result thus it was considered as the best priming medium, which can be supported by Dahiya et al., 2007.

Priming effects of different chemicals on germination of cotton seeds showed that priming with $\mathrm{KNO}_{3}$ increases germination features (Shim et al., 2008; Farhoudi, 2012; Siadat et al., 2012; Bian et al., 2013). Seed priming for germination, emergence and vigorous seedling varies according to the parameters, genotypes, chemicals and doses, but cold tolerance effect of $\mathrm{KNO}_{3}$ on seeds does not mostly remains unchanged (Dahiya et al., 2007). Priming with $\mathrm{KNO}_{3}(\% 2)$ increases germination rate and vigour in cold conditions. Results showed that after having sowed, priming with $\mathrm{KNO}_{3}$ increased germination between 3.75 and $22.04 \%$. When the priming effects of different PGRs on germination of cotton seeds were compared, the highest results were found to be in ASA, MeJA, GA 3 . Previous studies reported that priming with this PGRs were effective on wheat, maize and herbage species (Afzal et al., 2008; Jianhua et al., 1999). Priming with $\mathrm{KNO}_{3}$, Mannitol, $\mathrm{KH}_{2} \mathrm{PO}_{4}$ and $\mathrm{NaCl}$ are the best priming medium for all parameters.

Cotton seed priming and then germination at significantly increased germination percentage compared to control in Aydin 110 and Paymaster 2379. This results are important for cotton cold tolerance. As it was concluded by Rikin et al. (1979), primed seeds could be more resistant to cold environmental conditions.

PGRs mixed priming medium (second section) showed high germination results, but these results were lower than priming chemicals using alone (first section). Germination tests showed that is more effective to determine cotton germination rates.

This study showed that 2 hour priming with $\mathrm{KNO}_{3}$ and then drying (moisture $\sim 8 \%$ ) provided the seeds with cold tolerance and vigorous seedlings. Priming with $\mathrm{KNO}_{3}$ was an effective way to induce cold tolerance. Cotton seed priming with $\mathrm{KNO}_{3}(2 \%)$ can be suggested for the best germination results and vigorous seedlings in cold conditions.

\section{REFERENCES}

Afzal, I., S.M.A. Basra, M. Shahid, M. Farooq, M. Saleem. 2008. Priming enhances germination of spring maize (Zea mays L.) under cool conditions. Seed Sci Technol 36(2): 497-503.

Arif, M., M.T. Jan, I.A. Mian, S.A. Khan, P. Hollington, D. Harris. 2014. Evaluating the impact of osmopriming varying with polyethylene glycol concentrations and durations on soybean. IJAB 16: 2 .

Azymi, S., O. Sofalian, G.S. Jahanbakhsh, S. Khomari. 2012. Effect of chilling stress on soluble protein, sugar and prolin accumulation in cotton (Gossypium hirsutum L.) genotypes. Int J Agric Crop Sci 4(12): 825830 .

Bian, L., L. Yang, J.A. Wang, H.L. Shen. 2013. Effects of $\mathrm{KNO}_{3}$ pretreatment and temperature on seed germination of Sorbus pohuashanensis. J For Res 24(2): 309-316.

Dahiya, O.S., R.C. Punia, R.P.S. Kharb. 2007. Seed invigoration studies in cotton (Gossypium spp.). Nat J Plant Improv 9(1): 46-49. 
Dastanpoor, N., H. Fahimi, M. Shariati, S. Davazdahemami, S.M.M. Hashemi. 2013. Effects of hydropriming on seed germination and seedling growth in sage (Salvia officinalis L.). Afr J Biotechnol 12(11): 12231228.

Duan, L., X. Tian, Y. Zhang, Z. Tang, Z. Zhai, Z. He. 2004. Effects of mepiquat chloride on lateral roots initiation of cotton seedling and its mechanism. Proceedings of the 4th International Crop Science Congress, Brisbane, Australia.

Duesterhaus, B., N. Hopper, J. Gannaway, G.M. Jividen. 2000. Development of a laboratory screening test for the evaluation of cold tolerance in cotton seed germination. Proceedings of the Beltwide Cotton Conference 1: 621-623.

El-Nockrashy, A.S., H.M. Mostafa, Y. El-Shattory, M.H. Abbassy. 2006. Biochemical changes in cottonseed during germination. Mol Nutr Food Res 18(3): 285-293.

Farhoudi, R. 2012. Evaluation effect of $\mathrm{KNO}_{3}$ seed priming on seedling growth and cell membrane damage of sunflower (Heliantus annuus) under salt stress. American-Eurasian J. Agric \& Environ Sci 12(3): $384-$ 388.

Ghassemi-Golezani, K., A.A. Aliloo, M. Valizadeh, M. Moghaddam. 2008. Effects of different priming techniques on seed invigoration and seedling establishment of lentil (Lens culinaris Medik). J Food Agric Environ 6(2): 222-226.

Ghassemi-Golezani, K., S. Dastborhan, S. Zehtab-Salmasi. 2013. Seed priming and field performance of borage (Borago officinalis L.) under different irrigation treatments. Int J Agron Plant Prod 4(1): 82-87.

Guler, D., O.S. Turkmen, H. Turhan. 2007. The effects of $\mathrm{pH}$, salinity, and drought stress on seed germination in cotton. $7^{\text {th }}$ Field Crops Congress, Erzurum, Turkey.

Hameed, A., M.A. Sheikh, A. Jamil, S.M.A. Basra. 2013. Seed priming with sodium silicate enhances seed germination and seedling growth in wheat (Triticum aestivum L.) under water deficit stress induced by polyethylene glycol. Pak J Life Soc Sci 11(1): 19-24.

Hussian, I., R. Ahmad, M. Farooq, A. ur Rehman, M. Amin. 2014. Seed priming improves the performance of poor quality wheat seed under drought stress. Appl Sci Reports 3: 12-18.

Jackson, M.B. 1986. New root formation in plants and cuttings. Martinus Nijhoff Publishers 1-200.

Jianhua, S., W. Yanrong, Y. Ling, W. Dong. 1999. Effects of osmotic priming with polyethylene glycol on seed germination and vigour of some herbage species. Acta Prataculturae Sinica 8(2): 34-42.

Kaur, S., A.K. Gupta, N. Kaur. 2002. Effect of Osmo- and Hydropriming of chickpea seeds on seedling growth and carbohydrate metabolism under water deficit stres. Plant Growth Regul 37(1): 17-22.

Kerby, T.A., M. Keeley, S. Johnson. 1989. Weather and seed quality variables to predict cotton seedling emergence. Argon J 81: 415-419.

Lyons, J.M. 1973. Chilling injury in plants. Ann Rev Plant Physio 4: 445-466.

Mert, M., O. Gençer, Y. Akışcan K. Boyacı. 2003. Inheritance of yield and yield components in cotton (Gossypium hirsutum L.). Turk J Field Crops 8: 62-67.

Rikin, A., D. Atsmon, C. Gitler. 1979. Chilling injury in cotton (Gossypium hirsutum L.) prevention by abscisic acid. Plant Cell Physiol 20(8): 1537-1546.

Saeidi, M.R., A. Abdolghaium, M. Hassanzadeh, A. Rouhi, P. Nikzad. 2008. Investigation of seed priming on some germination aspects of different canola cultivars. J Food Agric Environ 6(2): 188-191.

Savoy, B.R. 2005. Cool germination test: principles and applications in cotton. Seed Technol 27(1): 127-129.

Shaheen, H.L., M. Shahbaz, I. Ullah, M.Z. Iqbal. 2012. Morpho-physiological responses of cotton (Gossypium hirsutum) to salt stres. Int J Agric Biol 14: 980-984.

Shim, S.I., J.C. Moon, C.S. Jang, P. Raymer, W. Kim. 2008. Effect of potassium nitrate priming on seed germination of seashore paspalum. Hortscience 43(7): 2259-2262.

Siadat, S.A., A. Moosavi, M.S. Zadeh. 2012. Effects of seed priming on antioxidant activity and germination characteristics of maize seeds under different ageing treatment. Res J Seed Sci 5(2): 51-62.

Smith, C.W., J.J. Varvil. 1984. Standard and cool germination tests compared with field emergence in upland cotton. Agron J 76(4): 587-589.

Theocharis, A., C. Clement, E.A. Barka. 2012. Physiological and molecular changes in plants grown at low temperatures. Planta 235: 1091-1105.

Tiryaki, I., Y. Buyukcingil. 2005. Effects of pre-seed treatments on seed germination and seedling emergence of maize (Zea mays L.) at low temperature. $2^{\text {nd }}$ Field Crops Congress, Adana, Turkey.

Tolliver, J., B.R. Savoy, E.A. Drummond. 1997. Cool germination test on cotton-variability between seedtesting laboratories. Proceedings Beltwide Cotton Conferences 1:442. 